\title{
Influence of mix application of ethephon with adjuvants and nitrogen fertilizers on growth and yield of spring barley
}

\author{
Wpływ łącznego stosowania etefonu z adiuwantami \\ i nawozami azotowymi na wzrost i plonowanie jęczmienia jarego
}

\author{
Wojciech Miziniak*, Jacek Piszczek
}

\begin{abstract}
Summary
The field experiments with spring barley cultivar KWS Olof were conducted in 2013-2014. The tested products (Cerone $480 \mathrm{SL}$ ), adjuvants (Slippa, Atpolan $80 \mathrm{EC}$ ) and fertilizers (ammonium sulfate, urea) and some of their mixtures were applied on spring barley at the stage of $\mathrm{BBCH} 35$. The higher effectiveness of shortening stems of spring barley was obtained after the use of Cerone $480 \mathrm{SL}$ at the dose of $0.75 \mathrm{l} / \mathrm{ha}$ as compared to the control. The reduction of spring barley stem length was dependent of spray liquid compounds and it was $9.7-13.0 \%$ (2013) and 2.6-11.0\% (2014) in the years of investigation, respectively. The addition of adjuvants Slippa or ammonium sulfate to the spray liquid containing ethephon improved efficacy of grown retardants. The method of application of ethephon did not have any influence on yield of spring barley and some parameters of yield component. However the usage of full or reduced doses of ethephon caused a non-significant decrease the thousand grain weight compared to the untreated plots. In both years of the study no phytotoxicity effect of the examined mixture was observed on spring barley cultivar KWS Olof.
\end{abstract}

Key words: spring barley; ethephon; adjuvants; ammonium sulfate; urea; yield

\section{Streszczenie}

Doświadczenia polowe prowadzono w uprawie jęczmienia jarego odmiany KWS Olof w latach 2013-2014. Badane preparaty (Cerone $480 \mathrm{SL}$ ), adiuwanty (Slippa, Atpolan $80 \mathrm{EC}$ ), nawozy (siarczan amonu, mocznik) oraz ich wybrane mieszaniny zastosowano w fazie strzelania w źdźbło (BBCH 35) jęczmienia jarego. W obydwu latach badań największe skrócenie długości źdźbeł w porównaniu do nietraktowanej kontroli uzyskano po zastosowaniu retardantu Cerone $480 \mathrm{SL}$ w dawce $0,75 \mathrm{I} / \mathrm{ha}$. Efektywność działania obniżonej dawki etefonu uzależniona była od składu mieszaniny i wynosiła w zależności od roku badań 9,7-13,0\% (2013) i 2,6-11,0\% (2014) skrócenia źdźbeł. Dodatek adiuwantu Slippa lub siarczanu amonu do cieczy opryskowej zawierającej etefon wpłynął na poprawienie efektywności działania retardantu wzrostu. Sposób stosowania etefonu nie miał istotnego wpływu na wybrane parametry struktury plonu. Natomiast zastosowanie etefonu w pełnej lub obniżonej dawce przyczyniło się do nieistotnego obniżenia masy tysiąca ziaren w porównaniu do kontroli. W obydwu latach badań nie stwierdzono fitotoksycznego oddziaływania badanych mieszanin na jęczmień jary odmiany KWS Olof.

Słowa kluczowe: jęczmień jary; etefon; adiuwanty; siarczan amonu; mocznik; plon

Instytut Ochrony Roślin - Państwowy Instytut Badawczy

Terenowa Stacja Doświadczalna

Pigwowa 16, 87-100 Toruń

*corresponding author: w.miziniak@iorpib.poznan.pl 


\section{Wstęp / Introduction}

Głównym celem nowoczesnego rolnictwa jest pozyskiwanie wysokich, dobrych jakościowo plonów zbóż. Zagwarantowanie stabilnego plonowania zbóż, uprawianych często w uproszczonym zmianowaniu lub w monokulturach, wiąże się z zagwarantowaniem intensywnej ochrony roślin ograniczającym niekorzystny wpływ agrofagów na rośliny uprawne. Nie mniej ważnym czynnikiem warunkującym uzyskanie wysokich plonów jest zabezpieczenie upraw przed wyleganiem roślin. W konsekwencji tego niekorzystnego zjawiska często dochodzi do spadku plonowania zbóż. Wyleganie powoduje ponadto wzrost kosztów związanych ze zbiorem, wydłuża czas konieczny do jego przeprowadzenia oraz obniża jakość ziarna (Sterry i wsp. 1980; Kelbert i wsp. 2004; Tripathi i wsp. 2004). W celu zmniejszenia ryzyka wylegania w intensywnej uprawie zbóż powszechnie stosowane są egzogenne związki ograniczające wzrost i rozwój roślin - retardanty wzrostu. W ochronie upraw jęczmienia jarego przed wyleganiem stosuje się dwie substancje czynne: trineksapak etylu oraz etefon.

Skuteczność działania środków ochrony roślin (ś.o.r.), w tym także retardantów wzrostu uzależniona jest między innymi od warunków klimatycznych (Toboła i Muśnicki 1998; Łęgowiak i Wysmułek 2000). Ograniczenie niekorzystnego wpływu zjawisk atmosferycznych na działanie ś.o.r. można uzyskać poprzez ich stosowanie z adiuwantami. Dodatkową korzyścią łącznego stosowania ś.o.r. $\mathrm{z}$ adiuwantami jest możliwość ograniczenia dawek tych preparatów bez utraty ich efektywności działania (Stachecki i wsp. 2004; Miziniak i Piszczek 2014).

Rozpuszczalność niektórych substancji czynnych herbicydów uzależniona jest od kwasowości cieczy użytkowej.
Według Green'a i Cahill'a (2003), Woźnicy i wsp. (2003) oraz Szeleźniaka (2005) zastosowanie odpowiedniego adiuwantu modyfikującego roztwór pH cieczy użytkowej wpływa na zwiększenie efektywności działania niektórych substancji czynnych herbicydów lub trineksapaku etylu (Miziniak 2003).

Celem przeprowadzonych badań było określenie możliwości redukcji dawek retardantów wzrostu poprzez łączne stosowanie $\mathrm{z}$ adiuwantami i nawozami azotowymi oraz zbadanie wpływu tych zabiegów na wzrost i plonowanie jęczmienia jarego.

\section{Materiały i metody / Materials and methods}

Doświadczenia polowe przeprowadzono w latach 2013-2014, w jęczmieniu jarym odmiany KWS Olof, w układzie losowanych bloków. Preparaty testowano w czterech powtórzeniach na poletkach o powierzchni $12 \mathrm{~m}^{2}$. Obiektami badań były: retardant wzrostu - etefon (Cerone 480 SL), adiuwanty - Slippa i Atpolan 80 EC oraz nawozy azotowe - siarczan amonu i mocznik oraz ich mieszanki. Wartości pH cieczy oznaczono w temperaturze $20^{\circ} \mathrm{C}$ za pomocą elektronicznego $\mathrm{pH}$-metru wyposażonego w szklaną elektrodę.

Aplikację badanych środków przeprowadzono w fazie 5. kolanka (BBCH 35) jęczmienia jarego. Szczegółowe informacje dotyczące terminów oraz dawek zastosowanych preparatów i ich mieszanin zbiornikowych przedstawiono w tabeli 1. Zabiegi wykonano opryskiwaczem rowerowym typu Victoria, wyposażonym w rozpylacze TeeJet 11002 VP, o wydatku cieczy opryskowej 2001 na ha. Ciśnienie robocze wynosiło $0,25 \mathrm{MPa}$.

Tabela 1. pH cieczy użytkowych zawierających mieszaniny etefonu z adiuwantami i nawozami

Table 1. $\mathrm{pH}$ of spray liquid containing ethephon with adjuvants and fertilizers

\begin{tabular}{|c|c|c|c|}
\hline $\begin{array}{l}\text { Lp. } \\
\text { No. }\end{array}$ & Obiekt - Treatment & $\begin{array}{l}\text { Dawka - Dose } \\
{[1, \mathrm{~kg} / \mathrm{ha}]}\end{array}$ & $\mathrm{pH}$ \\
\hline 1 & woda - water & - & 7,12 \\
\hline 2 & Cerone $480 \mathrm{SL}$ - ethephon & 0,75 & 2,28 \\
\hline 3 & Cerone $480 \mathrm{SL}$ - ethephon & 0,37 & 2,56 \\
\hline 4 & $\begin{array}{l}\text { Cerone } 480 \mathrm{SL}+\text { Slippa } \\
\text { ethephon }+ \text { organosilicone adjuvant (Slippa) }\end{array}$ & $0,37+0,1 \%$ & 2,56 \\
\hline 5 & $\begin{array}{l}\text { Cerone } 480 \mathrm{SL}+\text { Atpolan } 80 \mathrm{EC} \\
\text { ethephon }+ \text { mineral adjuvant (Atpolan } 80 \mathrm{EC} \text { ) }\end{array}$ & $0,37+1,5$ & 2,63 \\
\hline 6 & $\begin{array}{l}\text { Cerone } 480 \mathrm{SL}+\text { siarczan amonu } \\
\text { ethephon }+ \text { ammonium sulfate }\end{array}$ & $0,37+5,0$ & 3,35 \\
\hline 7 & $\begin{array}{l}\text { Cerone } 480 \mathrm{SL}+\text { mocznik } \\
\text { ethephon }+ \text { urea }\end{array}$ & $0,37+5,0$ & 2,53 \\
\hline 8 & $\begin{array}{l}\text { Cerone } 480 \mathrm{SL}+\text { Slippa }+ \text { siarczan amonu } \\
\text { ethephon }+ \text { organosilicone adjuvant }(\text { Slippa) }+ \text { ammonium sulfate }\end{array}$ & $0,37+0,1 \%+5,0$ & 3,27 \\
\hline 9 & $\begin{array}{l}\text { Cerone } 480 \mathrm{SL}+\text { Slippa }+ \text { mocznik } \\
\text { ethephon }+ \text { organosilicone adjuvant }(\text { Slippa })+\text { urea }\end{array}$ & $0,37+0,1 \%+5,0$ & 2,53 \\
\hline 10 & $\begin{array}{l}\text { Cerone } 480 \mathrm{SL}+\text { Atpolan } 80 \mathrm{EC}+\text { siarczan amonu } \\
\text { ethephon }+ \text { mineral adjuvant }(\text { Atpolan } 80 \mathrm{EC})+\text { ammonium sulfate }\end{array}$ & $0,37+1,5+5,0$ & 3,34 \\
\hline 11 & $\begin{array}{l}\text { Cerone } 480 \mathrm{SL}+\text { Atpolan } 80 \mathrm{EC}+\text { mocznik } \\
\text { ethephon }+ \text { mineral adjuvant }(\text { Atpolan } 80 \mathrm{EC})+\text { urea }\end{array}$ & $0,37+1,5+5,0$ & 2,66 \\
\hline
\end{tabular}


Pomiaru wysokości roślin dokonano w fazie dojrzałości woskowej ziarniaków (BBCH 83), mierząc po 25 losowo wybranych roślin z każdego poletka. Określano długość źdźbła od powierzchni gleby do podstawy kłosa. Wyleganie oceniano wizualnie za pomocą skali procentowej, w której przyjęto: $0 \%$ - brak wylegania (wszystkie rośliny na całej powierzchni poletek wyprostowane), 100\% całkowite wyleganie (wszystkie rośliny na całej powierzchni poletek ułożone poziomo). W okresie wegetacji roślin przeprowadzano systematyczne, wizualne oceny wpływu fitotoksycznego wpływu zastosowanych preparatów i ich mieszanin na rośliny jęczmienia jarego. W doświadczeniu zastosowano nawożenie mineralne na poziomie $80 \mathrm{~kg} \mathrm{~N}, 40 \mathrm{~kg} \mathrm{P}_{2} \mathrm{O}_{5}, 60 \mathrm{~kg} \mathrm{~K}_{2} \mathrm{O} / \mathrm{ha}$ oraz standardową ochronę przeciw chorobom i szkodnikom. Próby roślin do określenia struktury plonu pobrano $\mathrm{z}$ powierzchni $1 \mathrm{~m}^{2}$. Zamieszczone dane meteorologiczne pochodzą ze stacji zlokalizowanej w miejscu wykonywania doświadczeń polowych (Falęcin, Farol Sp. z o.o.).

Analizie statystycznej poddano dane dotyczące obsady, wysokości roślin, liczby ziaren w kłosie, plonów ziarna oraz masy tysiąca ziaren. Wyniki testu Fishera oceniano na poziomie istotności 1 i 5\%. Po stwierdzeniu istotnych różnic dokonano szczegółowego porównania średnich za pomocą testu t-Studenta, wyznaczając najmniejszą istotną różnicę na poziomie istotności 5\%.

\section{Wyniki i dyskusja / Results and discussion}

Efektywność działania retardantów wzrostu w dużej mierze uzależniona jest od warunków atmosferycznych. Według Toboły i wsp. (1998), średnia dobowa temperatura powietrza $\mathrm{w}$ największym stopniu determinuje skuteczność działania etefonu. Zdaniem autorów, skuteczność działania etefonu wzrasta wraz $\mathrm{z}$ temperaturą do $21^{\circ} \mathrm{C}$, natomiast $\mathrm{w}$ wyższej temperaturze powietrza zaczyna maleć. Największą redukcję wysokości źdźbeł jęczmienia jarego stwierdzono w 2013 roku. W latach 2013 i 2014 średnia dobowa temperatura powietrza $\mathrm{w}$ okresie $14 \mathrm{dni}$ po aplikacji etefonu wynosiła odpowiednio 16,6 oraz $17,8^{\circ} \mathrm{C}$ (tab. 2) i była niższa od optymalnej temperatury wyznaczonej przez Tobołę i wsp. (1998).

Najwyższą skuteczność retardacyjną stwierdzono po zastosowaniu zalecanej dawki retardantu. W zależności od roku badań preparat Cerone 480 SL ograniczył wysokość jęczmienia jarego w przedziale od 12,5 do $17,2 \%$ w porównaniu do kontroli (tab. 3). Zastosowanie obniżonej dawki etefonu, w zależności od roku badań, spowodowało spadek efektywności działania (rok 2013) lub nie wpłynęło na wysokość źdźbeł jęczmienia w porównaniu do kontroli (rok 2014).

W obydwu latach badań stwierdzono zróżnicowane działanie retardacyjne badanych mieszanin zbiornikowych. W 2013 roku, niezależnie od rodzaju zastosowanego adiuwantu oraz nawozu azotowego aplikowanego w mieszaninie $\mathrm{z}$ obniżonymi dawkami etefonu, biologiczna skuteczność mieszanin oscylowała na poziomie zmniejszonej dawki preparatu. Mimo braku istotnych różnic w wysokości źdźbeł, uwidoczniła się tendencja do polepszenia efektywności działania zredukowanej dawki retar- dantu stosowanego łącznie $\mathrm{z}$ adiuwantami i nawozami azotowymi. W 2014 roku, w większości ocenianych wariantów stwierdzono istotne polepszenie efektywność działania w porównaniu do zmniejszonej o 50\% dawki regulatora wzrostu.

Spośród badanych mieszanin największe ograniczenie wysokości źdźbeł odnotowano w wariantach badań, w których zastosowano etefon $\mathrm{z}$ adiuwantem Slippa lub z siarczanem amonu. W zależności od roku badań ograniczenie wzrostu elongacyjnego zawierało się w przedziale od 9,9 do $11 \%$ (łaczna aplikacja etefonu $\mathrm{z}$ adiuwantem Slippa) oraz od 12,2 do $10,5 \%$ (mieszanina etefonu $\mathrm{z}$ siarczanem amonu) w porównaniu do kontroli. Dodanie nawozów: siarczanu amonu lub mocznika do cieczy opryskowej zawierającej retardant oraz adiuwant organosilikonowy (Slippa) w obydwu latach badań nieznacznie osłabiło biologiczną efektywność działania tej mieszaniny. Odmienne wyniki uzyskano w przypadku oceny skuteczności działania mieszanin sporządzonych na bazie etefonu i adiuwantu mineralnego Atpolan 80 EC. Rozpuszczenie siarczanu amonu w cieczy opryskowej zawierającej retardant oraz adiuwant Atpolan 80 EC nie miało istotnego wpływu na efektywność działania, natomiast zastosowanie mocznika spowodowało nieznaczne osłabienie skuteczności działania tej mieszaniny zbiornikowej. Uzyskane wyniki nie zostały potwierdzone statystycznie.

W przeprowadzonych badaniach laboratoryjnych stwierdzono, że woda zastosowana do sporządzenia badanych roztworów charakteryzowała się odczynem obojętnym ( $\mathrm{pH}$ 7,12). Rozpuszczenie w wodzie etefonu obniżyło $\mathrm{pH}$ cieczy opryskowej do odczynu silnie kwaśnego (pH 2,28). Zastosowane adiuwanty (Slippa, Atpolan 80 EC) oraz nawozy nie wpłynęły na zmianę pH badanych roztworów. Nieznaczne podwyższenie $\mathrm{pH}$ odnotowano w cieczy opryskowej, w której rozpuszczono siarczan amonu $\mathrm{w}$ porównaniu do roztworu $\mathrm{z}$ etefonem. W zależności od składu mieszaniny zbiornikowej odczyn pH zawierał się w przedziale od 2,53 do 3,35 (tab. 1).

Zdaniem Green'a i Cahill'a (2003), Woźnicy i wsp. (2003) oraz Szeleźniaka (2005) pH cieczy opryskowej wpływa na efektywność działania niektórych herbicydów. Podobne spostrzeżenia dotyczące wpływu pH wykazał także Miziniak (2013) badając wpływ kwasowości cieczy opryskowej na skuteczność działania trineksapaku etylu. W przeprowadzonych doświadczeniach polowych nie udało się jednoznacznie określić wpływu pH cieczy opryskowej na skuteczność działania badanego retardantu wzrostu. W związku z powyższym zaistniała potrzeba kontynuowania dalszych badań nad określeniem możliwości polepszenia efektywności działania zredukowanych dawek etefonu w uprawie jęczmienia jarego.

Według licznych autorów, retardanty wzrostu wpływają na polepszenie plonowania zbóż, w tym także na poszczególne elementy struktury plonu, takie jak: liczba ziaren w kłosie oraz masa tysiąca ziarniaków (Starczewski i wsp. 2002). W odniesieniu do średniej liczby ziaren w kłosie, w większości publikacji naukowych zamieszczone są opinie o korzystnym wpływie retardantów wzrostu na omawiany parametr. Najwięcej kontrowersji wzbudza wpływ tych środków na masę tysiąca ziarniaków - MTZ (Giltrap i Garstang 1991; Woolley 1991; Starczewski i wsp. 2002). 
Tabela 2. Temperatura powietrza w okresie 14 dni po aplikacji preparatów

Table 2. Air temperature during14 days after the application of the growth regulators

\begin{tabular}{|c|c|c|c|c|c|c|}
\hline \multirow{4}{*}{$\begin{array}{l}\text { Lp. } \\
\text { No. }\end{array}$} & \multicolumn{6}{|c|}{ Rok badań - Years of investigation } \\
\hline & \multicolumn{3}{|c|}{2013} & \multicolumn{3}{|c|}{2014} \\
\hline & \multicolumn{3}{|c|}{$\begin{array}{l}\text { temperatura powietrza - air temperature } \\
{\left[{ }^{\circ} \mathrm{C}\right]}\end{array}$} & \multicolumn{3}{|c|}{$\begin{array}{l}\text { temperatura powietrza - air temperature } \\
{\left[{ }^{\circ} \mathrm{C}\right]}\end{array}$} \\
\hline & $\begin{array}{l}\text { maksymalna } \\
\text { maximum }\end{array}$ & $\begin{array}{l}\text { minimalna } \\
\text { minimum }\end{array}$ & $\begin{array}{l}\text { średnia dobowa } \\
\text { average daily }\end{array}$ & $\begin{array}{l}\text { maksymalna } \\
\text { maximum }\end{array}$ & $\begin{array}{c}\text { minimalna } \\
\text { minimum }\end{array}$ & $\begin{array}{l}\text { średnia dobowa } \\
\text { average daily }\end{array}$ \\
\hline 1 & 22,8 & 17,0 & 18,2 & 25,0 & 10,0 & 17,3 \\
\hline 2 & 18,0 & 12,5 & 14,4 & 23,0 & 14,0 & 18,1 \\
\hline 3 & 15,0 & 8,0 & 11,4 & 25,0 & 11,0 & 19,0 \\
\hline 4 & 22,0 & 10,0 & 16,0 & 29,0 & 15,0 & 21,2 \\
\hline 5 & 25,0 & 11,5 & 16,7 & 29,0 & 16,5 & 20,4 \\
\hline 6 & 25,5 & 10,2 & 18,1 & 28,0 & 16,0 & 21,5 \\
\hline 7 & 24,5 & 13,0 & 17,6 & 28,4 & 13,0 & 20,7 \\
\hline 8 & 13,2 & 13,0 & 14,4 & 25,0 & 16,0 & 19,3 \\
\hline 9 & 25,0 & 7,0 & 15,5 & 23,0 & 11,0 & 16,9 \\
\hline 10 & 24,0 & 12,0 & 18,3 & 19,0 & 10,0 & 14,1 \\
\hline 11 & 24,0 & 12,5 & 18,8 & 20,0 & 8,5 & 15,0 \\
\hline 12 & 22,0 & 16,0 & 18,7 & 22,0 & 5,5 & 14,8 \\
\hline 13 & 23,0 & 11,0 & 17,1 & 21,0 & 9,0 & 15,1 \\
\hline 14 & 22,0 & 13,0 & 18,0 & 23,0 & 7,0 & 15,8 \\
\hline $\begin{array}{l}\text { Średnia } \\
\text { Average }\end{array}$ & 21,9 & 11,9 & 16,6 & 24,3 & 11,6 & 17,8 \\
\hline
\end{tabular}

Tabela 3. Wpływ łącznego stosowania etefonu z adiuwantami na długość źdźbeł jęczmienia jarego

Table 3. Influence of mix application of ethephon with adjuvants on stem lenght of spring barley

\begin{tabular}{|c|c|c|c|c|c|c|c|c|}
\hline \multirow[b]{2}{*}{$\begin{array}{l}\text { Lp. } \\
\text { No. }\end{array}$} & \multirow[b]{2}{*}{$\begin{array}{l}\text { Obiekt } \\
\text { Treatment }\end{array}$} & \multirow[b]{2}{*}{$\begin{array}{l}\text { Dawka } \\
\text { Dose } \\
{[1, \mathrm{~kg} / \mathrm{ha}]}\end{array}$} & \multicolumn{2}{|c|}{$\begin{array}{c}\text { Fitotoksyczność } \\
\text { Phytotoxicity } \\
{[\%]}\end{array}$} & \multicolumn{4}{|c|}{$\begin{array}{l}\text { Długość źdźbeł } \\
\text { Stem length } \\
{[\mathrm{cm}]}\end{array}$} \\
\hline & & & 2013 & 2014 & 2013 & $\begin{array}{c}\text { redukcja } \\
\text { długości } \\
\text { źdźbeł } \\
\text { stem } \\
\text { length } \\
\text { reduction } \\
{[\%]}\end{array}$ & 2014 & $\begin{array}{c}\text { redukcja } \\
\text { długości } \\
\text { źdźbeł } \\
\text { stem } \\
\text { length } \\
\text { reduction } \\
{[\%]}\end{array}$ \\
\hline 1 & 2 & 3 & 4 & 5 & 6 & 7 & 8 & 9 \\
\hline 1 & kontrola - control & - & 0 & 0 & $63,7 \mathrm{a}$ & - & $61,6 \mathrm{ab}$ & - \\
\hline 2 & Cerone $480 \mathrm{SL}$ - ethephon & 0,75 & 0 & 0 & $52,7 \mathrm{~b}$ & 17,2 & $53,9 \mathrm{~d}$ & 12,5 \\
\hline 3 & Cerone $480 \mathrm{SL}$ - ethephon & 0,37 & 0 & 0 & $57,9 \mathrm{~b}$ & 9,1 & $62,5 \mathrm{a}$ & 0 \\
\hline 4 & $\begin{array}{l}\text { Cerone } 480 \text { SL + Slippa } \\
\text { ethephon }+ \text { organosilicone adjuvant (Slippa) }\end{array}$ & $0,37+0,1$ & 0 & 0 & $57,4 \mathrm{~b}$ & 9,9 & $54,8 \mathrm{~d}$ & 11,0 \\
\hline 5 & $\begin{array}{l}\text { Cerone } 480 \mathrm{SL}+\text { Atpolan } 80 \mathrm{EC} \\
\text { ethephon }+ \text { mineral adjuvant (Atpolan } 80 \mathrm{EC})\end{array}$ & $0,37+1,5$ & 0 & 0 & $57,5 \mathrm{~b}$ & 9,7 & $60,0 a b c$ & 2,6 \\
\hline 6 & $\begin{array}{l}\text { Cerone } 480 \mathrm{SL}+\text { siarczan amonu } \\
\text { ethephon }+ \text { ammonium sulfate }\end{array}$ & $0,37+5,0$ & 0 & 0 & $55,9 \mathrm{~b}$ & 12,2 & $55,1 \mathrm{~d}$ & 10,5 \\
\hline 7 & $\begin{array}{l}\text { Cerone } 480 \mathrm{SL}+\text { mocznik } \\
\text { ethephon }+ \text { urea }\end{array}$ & $0,37+5,0$ & 0 & 0 & $56,4 \mathrm{~b}$ & 11,4 & $57,7 \mathrm{bcd}$ & 6,3 \\
\hline 8 & $\begin{array}{l}\text { Cerone } 480 \mathrm{SL}+\text { Slippa + siarczan amonu } \\
\text { ethephon + organosilicone adjuvant (Slippa) } \\
+ \text { ammonium sulfate }\end{array}$ & $\begin{array}{l}0,37+0,1 \\
\quad+5,0\end{array}$ & 0 & 0 & $56,7 \mathrm{~b}$ & 11,0 & $57,3 \mathrm{bcd}$ & 7,0 \\
\hline
\end{tabular}




\begin{tabular}{|c|c|c|c|c|c|c|c|c|}
\hline 1 & 2 & 3 & 4 & 5 & 6 & 7 & 8 & 9 \\
\hline 9 & $\begin{array}{l}\text { Cerone } 480 \mathrm{SL}+\text { Slippa }+ \text { mocznik } \\
\text { ethephon }+ \text { organosilicone adjuvant (Slippa) } \\
+ \text { urea }\end{array}$ & $\begin{array}{c}0,37+0,1 \\
\quad+5,0\end{array}$ & 0 & 0 & $56,8 \mathrm{~b}$ & 10,8 & $56,2 \mathrm{~cd}$ & 8,8 \\
\hline 10 & $\begin{array}{l}\text { Cerone } 480 \mathrm{SL}+\text { Atpolan } 80 \mathrm{EC}+\text { siarczan } \\
\text { amonu } \\
\text { ethephon }+ \text { mineral adjuvant (Atpolan } 80 \mathrm{EC}) \\
+ \text { ammonium sulfate }\end{array}$ & $\begin{array}{c}0,37+1,5 \\
\quad+5,0\end{array}$ & 0 & 0 & $55,4 \mathrm{~b}$ & 13,0 & $55,2 \mathrm{~d}$ & 10,4 \\
\hline 11 & $\begin{array}{l}\text { Cerone } 480 \mathrm{SL}+\text { Atpolan } 80 \mathrm{EC}+\text { mocznik } \\
\text { ethephon }+ \text { mineral adjuvant (Atpolan } 80 \mathrm{EC}) \\
+ \text { urea }\end{array}$ & $\begin{array}{c}0,37+1,5 \\
\quad+5,0\end{array}$ & 0 & 0 & $56,6 \mathrm{~b}$ & 11,1 & $58,0 \mathrm{bcd}$ & 5,8 \\
\hline \multicolumn{2}{|c|}{$\operatorname{NIR}(0,05)-\operatorname{LSD}(0.05)$} & - & - & - & 5,34 & - & 4,25 & - \\
\hline
\end{tabular}

Termin aplikacji BBCH 35 jęczmienia jarego - Time of application BBCH 35 of spring barley

Wartości liczbowe oznaczone tą samą literą nie różnią się istotnie przy $\mathrm{p}=0,05$

Values followed by the same letter are not significantly different $(\mathrm{p}=0.05)$

Tabela 4. Wpływ łącznego stosowania etefonu z adiuwantami na wybrane parametry struktury plonu

Table 4. Influence of mix application ethephon with adjuvants on some parameters of yield

\begin{tabular}{|c|c|c|c|c|c|c|c|c|}
\hline \multirow[t]{2}{*}{$\begin{array}{l}\text { Lp. } \\
\text { No. }\end{array}$} & \multirow[t]{2}{*}{$\begin{array}{l}\text { Obiekt } \\
\text { Treatment }\end{array}$} & \multirow[t]{2}{*}{$\begin{array}{l}\text { Dawka } \\
\text { Dose } \\
{[1, \mathrm{~kg} / \mathrm{ha}]}\end{array}$} & \multicolumn{2}{|c|}{$\begin{array}{l}\text { MTZ } \\
\text { The thousand } \\
\text { grain weight } \\
{[\mathrm{g}]}\end{array}$} & \multicolumn{2}{|c|}{$\begin{array}{c}\text { Liczba } \\
\text { ziaren w kłosie } \\
\text { [szt./kłos] } \\
\text { Number } \\
\text { of grain per earn } \\
\text { [pcs/ear] }\end{array}$} & \multicolumn{2}{|c|}{$\begin{array}{l}\text { Plon } \\
\text { Yield } \\
{[\mathrm{t} / \mathrm{ha}]}\end{array}$} \\
\hline & & & 2013 & 2014 & 2013 & 2014 & 2013 & 2014 \\
\hline 1 & kontrola - control & - & $48,87 \mathrm{a}$ & $47,06 \mathrm{a}$ & $17,8 \mathrm{a}$ & $17,8 \mathrm{a}$ & $6,24 \mathrm{ab}$ & $6,71 \mathrm{a}$ \\
\hline 2 & Cerone $480 \mathrm{SL}$ - ethephon & 0,75 & $46,12 \mathrm{abc}$ & $46,95 \mathrm{a}$ & $18,8 \mathrm{a}$ & $17,8 \mathrm{a}$ & $5,85 \mathrm{~b}$ & $6,67 \mathrm{a}$ \\
\hline 3 & Cerone $480 \mathrm{SL}$ - ethephon & 0,37 & $42,05 \mathrm{bc}$ & 45,12 a & $17,1 \mathrm{a}$ & $18,3 \mathrm{a}$ & $6,25 \mathrm{ab}$ & $6,78 \mathrm{a}$ \\
\hline 4 & $\begin{array}{l}\text { Cerone } 480 \mathrm{SL}+\text { Slippa } \\
\text { ethephon }+ \text { organosilicone adjuvant (Slippa) }\end{array}$ & $0,37+0,1$ & $44,31 \mathrm{abc}$ & 45,39 a & $18,5 \mathrm{a}$ & $18,2 \mathrm{a}$ & $6,05 \mathrm{ab}$ & $6,97 \mathrm{a}$ \\
\hline 5 & $\begin{array}{l}\text { Cerone } 480 \mathrm{SL}+\text { Atpolan } 80 \mathrm{EC} \\
\text { ethephon }+ \text { mineral adjuvant (Atpolan } 80 \mathrm{EC} \text { ) }\end{array}$ & $0,37+1,5$ & $45,81 \mathrm{abc}$ & 45,44 a & $18,1 \mathrm{a}$ & $18,4 \mathrm{a}$ & $7,06 \mathrm{ab}$ & $7,38 \mathrm{a}$ \\
\hline 6 & $\begin{array}{l}\text { Cerone } 480 \mathrm{SL}+\text { siarczan amonu } \\
\text { ethephon }+ \text { ammonium sulfate }\end{array}$ & $0,37+5,0$ & $42,55 \mathrm{bc}$ & 45,77 a & $18,5 \mathrm{a}$ & $18,1 \mathrm{a}$ & $6,35 \mathrm{ab}$ & $7,12 \mathrm{a}$ \\
\hline 7 & $\begin{array}{l}\text { Cerone } 480 \mathrm{SL}+\text { mocznik } \\
\text { ethephon + urea }\end{array}$ & $0,37+5,0$ & $45,74 \mathrm{abc}$ & 44,56 a & $18,5 \mathrm{a}$ & $19,1 \mathrm{a}$ & $6,54 \mathrm{ab}$ & $6,63 \mathrm{a}$ \\
\hline 8 & $\begin{array}{l}\text { Cerone } 480 \mathrm{SL}+\text { Slippa }+ \text { siarczan amonu } \\
\text { ethephon }+ \text { organosilicone adjuvant (Slippa) }+ \\
\text { ammonium sulfate }\end{array}$ & $0,37+0,1+5,0$ & $43,38 \mathrm{abc}$ & 45,35 a & $18,9 \mathrm{a}$ & $18,3 \mathrm{a}$ & $7,19 \mathrm{ab}$ & $7,04 \mathrm{a}$ \\
\hline 9 & $\begin{array}{l}\text { Cerone } 480 \mathrm{SL}+\text { Slippa }+ \text { mocznik } \\
\text { ethephon }+ \text { organosilicone adjuvant (Slippa) }+ \text { urea }\end{array}$ & $0,37+0,1+5,0$ & $41,56 \mathrm{c}$ & 44,06 a & $18,0 \mathrm{a}$ & $17,9 \mathrm{a}$ & $5,91 \mathrm{ab}$ & $6,58 \mathrm{a}$ \\
\hline 10 & $\begin{array}{l}\text { Cerone } 480 \mathrm{SL}+\text { Atpolan } 80 \mathrm{EC}+\text { siarczan amonu } \\
\text { ethephon }+ \text { mineral adjuvant (Atpolan } 80 \mathrm{EC})+ \\
\text { ammonium sulfate }\end{array}$ & $0,37+1,5+5,0$ & $48,28 \mathrm{ab}$ & 43,98 a & $17,9 \mathrm{a}$ & $18,2 \mathrm{a}$ & $6,93 \mathrm{ab}$ & $6,88 \mathrm{a}$ \\
\hline 11 & $\begin{array}{l}\text { Cerone } 480 \mathrm{SL}+\text { Atpolan } 80 \mathrm{EC}+\text { mocznik } \\
\text { ethephon }+ \text { mineral adjuvant (Atpolan } 80 \mathrm{EC})+ \text { urea }\end{array}$ & $0,37+1,5+5,0$ & $45,49 \mathrm{abc}$ & $44,67 \mathrm{a}$ & $17,9 \mathrm{a}$ & $18,3 \mathrm{a}$ & $7,31 \mathrm{a}$ & $7,22 \mathrm{a}$ \\
\hline NIR & $(0,05)-\operatorname{LSD}(0.05)$ & - & 6,30 & r.n. & r.n. & r.n. & 1,40 & r.n. \\
\hline
\end{tabular}

Termin aplikacji BBCH 35 jęczmienia jarego - Time of application BBCH 35 of spring barley

r.n. - różnica nieistotna - not significant difference

Wartości liczbowe oznaczone tą samą literą nie różnią się istotnie przy p $=0,05$

Values followed by the same letter are not significantly different $(p=0.05)$

W doświadczeniach własnych nie stwierdzono istotnego wpływu badanych mieszanin na średnią liczbę ziarniaków w kłosie. Odnotowano natomiast, że niezależnie od dawki retardantu wzrostu, uzyskane ziarno jęczmienia odznaczało się nieznacznie mniejszą masą tysiąca ziarniaków w porównaniu do kontroli. W większości analizowanych wariantów badań sposób aplikacji obniżonej dawki etefonu (sam etefon lub $\mathrm{z}$ dodatkiem 
adiuwantu lub nawozu azotowego) nie miał istotnego wpływu na badaną cechę. Jednakże w 2013 roku odnotowano obniżenie MTZ w wariancie, w którym zastosowano mieszaninę etefonu $\mathrm{z}$ adiuwantem Slippa i mocznikiem. Zaistniałe relacje uwidoczniły się jedynie w pierwszym roku badań, natomiast sposób aplikacji retardantu nie miał istotnego wpływu na MTZ w 2014 roku.

Największe różnice w zebranej masie ziarna (potwierdzone statystycznie) między badanymi wariantami były widoczne w pierwszym roku badań (2013 rok). Spośród ocenianych wariantów, istotne różnice w plonie ziarna uzyskano pomiędzy pełną dawką etefonu (obniżenie plonowania) oraz w wariancie badań, w którym zastosowano mieszaninę obniżonej dawki etefonu $\mathrm{z}$ adiuwantem Atpolan 80 EC i mocznikiem (wzrost plonowania) w porównaniu do kontroli. W 2014 roku sposób aplikacji etefonu (sam etefon lub mieszanina $\mathrm{z}$ adiuwantami i nawozami azotowymi) nie miał istotnego wpływu na plonowanie rośliny uprawnej.

Niezależnie od lat badań nie stwierdzono fitotoksycznego oddziaływania badanych mieszanin zbiornikowych na jęczmień jary odmiany KWS Olof.

\section{Wnioski / Conclusions}

1. Największą redukcję w długości źdźbeł jęczmienia jarego uzyskano po zastosowaniu zalecanej (pełnej) dawki retardantu wzrostu Cerone 480 SL (etefon). Obniżenie dawki o $50 \%$ badanego regulatora wzrostu spowodowało obniżenie jego skuteczności działania.

2. Łączne stosowanie etefonu (Cerone 480 SL) w obniżonej dawce $\mathrm{z}$ adiuwantami i nawozami daje możliwości znacznego skrócenia źdźbła. Wskazane są dalsze badania nad określeniem warunków sprzyjających efektywniejszemu działaniu etefonu w obniżonej dawce.

3. Niezależnie od lat badań testowane mieszaniny nie miały istotnego wpływu na liczbę ziarniaków w kłosie oraz plon jęczmienia jarego. Zaobserwowano natomiast tendencję do obniżenia MTZ w porównaniu do obiektu kontrolnego.

4. W dwuletnich badaniach polowych nie stwierdzono fitotoksycznego oddziaływania zarówno etefonu stosowanego samodzielnie, jak i w mieszaninach zbiornikowych z adiuwantami czy nawozami azotowymi na rośliny jęczmienia jarego odmiany KWS Olof.

\section{Literatura / References}

Giltrap N.J., Garstang J.R. 1991. Effect of PGRS and nitrogen rate on grain yield and quality of Marinka winter barley. The BCPC Conference -Weeds 7C-10: 987-994.

Green J.M., Cahill W.R. 2003. Enhancing the biological activity of nicosulfuron with pH adjusters. Weed Technology 17: 338-345.

Kelbert A.J., Spaner D., Briggs K.G., King J.R. 2004. The association of culm anatomy with lodging susceptibility in modern spring wheat genotypes. Euphytica 136: 211-221.

Łęgowiak Z., Wysmułek A. 2000. Stosowanie regulatorów wzrostu w zbożach. [Plant growth regulators in cereals]. Progress in Plant Protection/Postępy w Ochronie Roślin 40 (2): 932-934.

Miziniak W. 2013. Wpływ kwasowości cieczy opryskowej na skuteczność działania wybranych retardantów wzrostu stosowanych w uprawie jęczmienia jarego. [Influence of spray liquid acidity on effectiveness of some growth regulators in spring barley crops]. Progress in Plant Protection/Postepy w Ochronie Roślin 53 (4): 817-821.

Miziniak W., Piszczek J. 2014. Biologiczna aktywność retardantów stosowanych z adiuwantami w uprawie pszenicy ozimej. [Biological activity of growth regulators used with adjuvants in winter wheat crops]. Progress in Plant Protection 54 (4): 476-480.

Toboła P., Muśnicki Cz. 1998. Wpływ etefonu na wzrost, rozwój i plonowanie słonecznika oleistego. Materiały 35. Sesji Naukowej Instytutu Ochrony Roślin, cz. 1: 338-341.

Toboła P., Muśnicki Cz., Szmyt H. 1998. Efektywność etefonu w skracaniu słonecznika oleistego w zależności od niektórych elementów pogody. [Ethephon efficiency on oilseed sunflower shortening depending on some weather elements]. Biuletyn Instytutu Hodowli i Aklimatyzacji Roślin, Rośliny Oleiste XIX (I): 293-300.

Tripathi S.C., Sayre K.D., Kaul J.N., Narang R.S. 2004. Lodging behavior and yield potential of spring wheat (Triticum aestivum L.) effects of ethephon and genotypes. Field Crops Research 87: 207-220.

Stachecki S., Praczyk T., Adamczewski K. 2004. Adjuvant effects on plant growth regulators in winter wheat. Journal of Plant Protection Research 44 (4): 365-371.

Starczewski J., Bombik A., Dopka D. 2002. Plonowanie i struktura plonu pszenżyta ozimego w zależności od nawożenia azotem i wybranych retardantów. Folia Universitatis Agriculturae Stetinenesis. Agricultura 228 (91): 147-154.

Sterry J.R. 1980. Ethephon as a plant growth regulator on winter barley: results and present status in Europe. The BCPC ConferenceWeeds: 687-692.

Szeleźniak E. 2005. Wpływ związków mineralnych i organicznych modyfikujących pH cieczy opryskowej na skuteczność działania tralkoksydymu. [Effect of mineral and organic compounds modifying spray $\mathrm{pH}$ on tralkoxydim efficasy]. Pamiętnik Puławski 140: 297-309.

Woolley E.W. 1991. Recent experience of timing of growth regulators on winter wheat. The BCPC Conference -Weeds 7C-10: 981986.

Woźnica Z., Nalewaja J.D., Messershmith G., Milkowski P. 2003. Quinclorac efficasy as effected by adjuvants and spray carrier water. Weed Technology 17: 582-588. 